\title{
ЩОДО РОЗМЕЖУВАННЯ ВІЙСЬКОВИХ АДМІНІСТРАТИВНИХ ПРАВОПОРУШЕНЬ ВІД КРИМІНАЛЬНИХ ПРАВОПОРУШЕНЬ
}

\begin{abstract}
ПОДОЛЯКА Анатолій Миколайович - доктор юридичних наук, професор, Заслужений юрист України, завідувач кафедри теорії держави і права та конституційного права ПрАТ «ВНЗ «Міжрегіональна Академія управління персоналом".

ДЬОМІН Юрій Михайлович - доктор юридичних наук, професор, Заслужений юрист України, адвокат.
\end{abstract}

DOI 10.32782/LAW.UA.2021.2.7

Авторами статьи предпринята попьттка предоставить родовую характеристику военнъим административнъим правонарушением, предложить условнъе критерии, которье можно использовать для отделения правовых институтов административной и уголовной ответственности за правонарушения в военной сфере.

Особую остроту проблематике разграничения административньих и уголовньих правонарушений добавляет ведения против Украинъ гибридной войнъ, что приводит к возможности использования отдельньхх правонарушений, совершенных военнослужащими, как инбормационньгх поводов для пропагандь и контрпропагандъ .

Очерчен круг объектов правонарушений в военной сбере. В наиболее обобщенном смысле, родовъим объектом военнъхх административньих правонарушений является установленнълй порядок прохождения военной службъ, хранения и использования военного имущества, осуществления военнълми должностньли лицами своuх функииональныхх обязанностей. При этом непосредственнъмм объектом правонарушения, в частности, может бътть внутренний порядок в воинской части.

Въляснено, что при квалификаиии действий правонарушителей важно учитьлвать различия, которьи существуют в разньх родах войск, их дислокачии, подчинения, назначения или цуели их создания, специиального статуса таких подразделений и тому подобное. При этом, определяюшим бактором разграничения квалификации правонарушений может выступать общественно опасньй характер причиненньх последствий.

Авторь констатируют важность роли военной прокуратурь в разграничении административнъгх и уголовньгх правонарушений в военной сфере. Отмечается своевременность восстановления работь военной прокуратурь и необходимость дальнейших исследований особенностей ее деятельности в условиях ведения боевъих действий.

Ключевъие слова: правосудие, прокуратура, военнъие прокурорь, военнъие административнъие правонарушения, военнъге уголовнъие правонарушения.

Актуальність теми дослідження обумовлена рядом чинників, зокрема - необхідністю повноцінної реалізації прав і свобод людини і громадянина, закріплених Конституцією України, потребою дотримання правопорядку, важливістю виокремлення критеріїв, які можна використовувати для відокремлення правових інститутів адміністративної та кримінальної відповідальності за правопорушення у військовій сфері.

Окремим фактором, що загострюе проблематику розмежування військових адміністративних правопорушень від кримінальних правопорушень, є ведення проти України гібридної війни, що передбачає використання наслідків дій чи бездіяльності українських військовослужбовців як інформаційної основи для формування пропагандистських кліше, 3 подальшим їх 


\section{Адміністративне право}

поширенням як у усередині держави, так i за кордоном.

\section{Короткий огляд досліджень і публі- кацій 3 аналізованої тематики}

Тематиці розмежування адміністративних та кримінальних правопорушень присвячували свою увагу як вітчизняні, так і зарубіжні вчені. Зокрема, особливості адміністративних правопорушень у військовій сфері розглядали у своїх працях такі вітчизняні дослідники, як О. В. Міхед, А. В. Столітній, М. С. Туркот. Однак, наявність суперечностей у чинному законодавстві та ведення бойових дій на території нашої держави загострюють актуальність нових досліджень окресленої тематики.

\section{Основний зміст дослідження}

Згідно зі статтею 131-1 Конституції України в Україні діє прокуратура, яка здійснює: 1) підтримання публічного обвинувачення в суді; 2) організацію і процесуальне керівництво досудовим розслідуванням, вирішення відповідно до закону інших питань під час кримінального провадження, нагляд за негласними та іншими слідчими і розшуковими діями органів правопорядку; 3) представництво інтересів держави в суді у виняткових випадках і в порядку, що визначені законом [1, ст. 131-1]. Власне статус прокурора визначений статтею 15 Закону України «Про прокуратуру» 3 урахуванням спеціалізації органів військової прокуратури. Згідно з частиною 7 ст. 23 Закону України «Про прокуратуру» під час здійснення представницьких повноважень прокурор у разі встановлення ознак адміністративного правопорушення зобов'язаний здійснити передбачені законом дії щодо порушення відповідного провадження [2]. Цими повноваженнями наділена також і військова прокуратура, яка входить до системи органів прокуратури України.

Відповідно до частини четвертої статті 15 Кодексу України про адміністративне правопорушення (далі - КУпАП) військовослужбовці за вчинення військових адміністративних правопорушень несуть відповідальність, передбачену главою 13-Б цього Кодексу, за умови, якщо ці правопорушення не тягнуть за собою кримінальну відповідальність [3, ст. 15]. При цьому, адміністративним правопорушенням (проступком) визнається протиправна, винна (умисна або необережна) дія чи бездіяльність, яка посягає на громадський порядок, власність, права і свободи громадян, на встановлений порядок управління і за яку законом передбачено адміністративну відповідальність. Адміністративна ж відповідальність за правопорушення настає, якщо ці порушення за своїм характером не тягнуть за собою відповідно до закону кримінальної відповідальності [2, ст. 9].

Визначення злочину міститься у статті 11 Кримінального кодексу України (далі - КК України). Кримінальним правопорушенням є передбачене КК України суспільно небезпечне винне діяння (дія або бездіяльність), вчинене суб'єктом кримінального правопорушення.

Не є кримінальним правопорушенням дія або бездіяльність, яка хоча формально і містить ознаки будь-якого діяння, передбаченого КК України, але через малозначність не становить суспільної небезпеки, тобто не заподіяла і не могла заподіяти істотної шкоди фізичній чи юридичній особі, суспільству або державі [4, ст.11]

У Розділі ХІХ КК України міститься вичерпний перелік злочинів проти встановленого порядку несення військової служби (військові злочини) [4]. Однак, з огляду на відносну тотожність окремих назв статей розділу XIX («Злочини проти встановленого порядку несення військової служби») КК України та глави 13-Б КУпАП («Військові адміністративні правопорушення») постає питання правильності кваліфікації дій військовослужбовців та відмежування юридичних складів адміністративних правопорушень (проступків) від кримінальних правопорушень, що i зроблено науковцями Національної академії прокуратури України. Зокрема, на основі всебічного та системного аналізу правових норм різних галузей законодавства групою науковців була запропонована Порівняльна таблиця складів військових адміністративних правопорушень, передбачених КУпАП, та 
кримінальних правопорушень, передбачених КК України [5].

Відповідно до статті 253 КУпАП, якщо при розгляді справи орган (посадова особа) прийде до висновку, що в порушенні $\epsilon$ ознаки кримінального правопорушення, він передає матеріали прокурору або органу досудового розслідування [2, ст. 253]. Водночас, у посібнику «Військові адміністративні правопорушення» надано науково-практичний коментар до кожної з одинадцяти статей Глави 13-Б КУпАП, що стосуються військових адміністративних правопорушень. Тому, на наш погляд, буде зайвим у статті дублювати положення, які передбачають відповідальність за військові адміністративні правопорушення постатейно [5].

Пропонується надати не тільки аналітично-правову, родову характеристику двом правовим інститутам відповідальності у військовій сфері, а запропонувати примірні критерії щодо розмежування військових поступків від військових злочинів, порівняти ці два самостійні правові інститути, провести подальший аналіз їх основних понять та норм.

На думку окремих науковців, однією 3 основних ознак відмежування адміністративних правопорушень, передбачених ст. ст. 172-12 - 172-16 КУпАП, від кримінальних правопорушень $є$ рівень суспільної небезпеки, розмір заподіяної шкоди й інші чинники [5].

Зокрема, розраховуючи розмір заподіяної шкоди у 2021 році, слід враховувати вимоги пункту 5 підрозділу 1 розділу ХХ Податкового кодексу України, яким установлено, що для норм адміністративного та кримінального законодавства в частині кваліфікації злочинів або правопорушень сума неоподатковуваного мінімуму встановлюється на рівні податкової соціальної пільги, визначеної підпунктом 169.1.1 пункту 169.1 статті 169 розділу IV цього Кодексу для відповідного року у розмірі, що дорівнюе 50 відсоткам розміру прожиткового мінімуму для працездатної особи, встановленому законом на 1 січня звітного податкового року [6].

До інших критеріїв відмінностей між адміністративними проступками та кри- мінальними правопорушеннями хотілося перейти після більш детального аналізу та розгляду основних складових військових адміністративних правопорушень (поступків).

Для правильної кваліфікації дій правопорушників за статтями КУпАП насамперед необхідно з'ясувати безпосередній об'єкт адміністративного правопорушення, на що саме направлене посягання в більшості випадках, зокрема, проаналізувати правові відносини «підлеглості».

Родовим об'єктом військових адміністративних правопорушень є установлений порядок проходження (здійснення, несення) військової (прикордонної) служби, зберігання та використання військового майна, здійснення військовими службовими особами своїх функціональних обов'язків, організації життедіяльності у військових колективах та здійснення військовими командирами (начальниками) своїх функцій, несення бойового чергування або бойової служби, поводження зі зброєю, експлуатації військової спеціальної техніки, поводження 3 речовинами і предметами, що становлять підвищену небезпеку для оточення, радіоактивними матеріалами.

Безпосереднім об'єктом правопорушення, зокрема, може бути внутрішній порядок у військовій частині, який зобов'язує військовослужбовців бездоганно і неухильно дотримуватись порядку і правил, встановлених військовими статутами та законами України. При цьому, правові підстави організації та порядку несення бойового чергування визначені розділом 9 Статуту внутрішньої служби Збройних Сил України (статті $332-341)$.

Правовою основою відносин між начальниками та підлеглими військовослужбовцями, старшими і молодшими за військовим званням є положення ст. ст. 28-32 Статуту внутрішньої служби Збройних Сил України, затвердженого Законом України від 24.03.1999 № 548-XIV.

Відповідно до ст. 28 цього Статуту єдиноначальність полягає у наділенні командира всією повнотою розпорядчої влади стосовно підлеглих і покладенні на нього персональної відповідальності за діяльність 


\section{Адміністративне право}

військової частини, підрозділу і кожного військовослужбовця, наданні командирові (начальникові) права одноособово приймати рішення, віддавати накази; забезпеченні виконання зазначених рішень (наказів), виходячи із всебічної оцінки обстановки та керуючись вимогами законів і статутів Збройних Сил України.

Згідно зі ст. 30 Статуту внутрішньої служби Збройних Сил України начальник має право віддавати підлеглому накази i зобов'язаний перевіряти їх виконання. Підлеглий зобов'язаний беззастережно виконувати накази начальника, крім випадків явно злочинного наказу. Статутом також визначені прямі та безпосередні начальники (ст. ст. 31, 32), а також начальники залежно від їх військових звань [7].

Таким чином, військовим начальником потрібно вважати військовослужбовця (військовозобов' язаного на час проходження зборів), який має підлеглих за посадою або за військовим званням, наділений правом пред'являти до них обов'язкові для виконання вимоги, пов'язані $з$ проходженням або несенням військової служби, а також застосовувати передбачені чинним законодавством заходи заохочення та стягнення.

У статтях Глави 13-Б КУпАП є посилання на військових службових осіб, у той же час у статті 14 КУпАП мова йде про відповідальність посадових осіб, у разі незабезпечення ними виконання покладених на них службових обов'язків [2, ст. 14].

У науково-практичному коментарі глави 13-Б КУпАП цьому питанню приділена увага $з$ посилкою на законодавство у військовій сфері [5].

При кваліфікації дій правопорушників слід також враховувати відмінності, які існують у різних родах військ, їх дислокації, підпорядкуванні, призначення або меті їх створення, спеціальному статусі таких підрозділів тощо.

Зокрема, у Державній прикордонній службі існують різні самостійні структурні підрозділи, 3 урахуванням їхніх функцій та повноважень. Це контрольно-пропускні пункти (КПП) та прикордонні застави на ділянках державного кордону на місцевості (на воді, на землі), що передбачено законодавчо.

Суб'єктами військового адміністративного правопорушення можуть бути як військовослужбовці строкової військової служби, так і будь-які інші військовослужбовці, у залежно від диспозиції конкретної статті Глави 13-Б КУПАП.

Згідно 3 приміткою до статті 172-13 КУпАП суб'єктом військових адміністративних правопорушень можуть бути також військові службові особи, під якими розуміються військові начальники, а також інші військовослужбовці, які обіймають постійно чи тимчасово посади, пов'язані з виконанням організаційно-розпорядчих чи адміністративно-господарських обов'язків, або виконують такі обов'язки за спеціальним дорученням повноважного командування (аналогічно у статтях 172-14-172-16 КУпАП) [2].

Особливістю складу адміністративного правопорушення, передбаченого ст.172-18 КУПАП, є спеціальний суб'єкт. До відповідальності можуть бути притягнуті лише ті військовослужбовці, які входять до складу будь-якого 3 нарядів, завданням яких є охорона державного кордону України. Таким нарядом визнається група озброєних прикордонників, що виконують наказ з охорони державного кордону України та заступають на його охорону.

Початок і кінець перебування в складі такого наряду визначається моментом отримання наказу на охорону державного кордону і доповіддю відповідному командиру про повернення з наряду.

Особа, яка виконує обов'язки посадової (службової) особи прикордонної служби, у т. ч. пов'язані з організацією несення прикордонної служби, але не входить до складу наряду з охорони державного кордону України (начальник застави, його заступники, начальник КПП, його заступники, помічники та інші), а також члени громадського формування 3 охорони громадського порядку і державного кордону, не 6 суб'єктом цього правопорушення.

Об'єктивну сторону військових адміністративних правопорушень можна вважати одним 3 важливих елементів їхнього 
складу, який охоплює ознаки, що характеризують адміністративний проступок із точки зору його зовнішнього прояву. Він містить більше інформації, необхідної для кваліфікації проступку за статтями КУпАП, якщо відсутній склад кримінального правопорушення. У диспозиціях статей КУпАП відображається саме об'єктивна сторона адміністративного проступку.

Наприклад, об'єктивна сторона адміністративного проступку, передбаченого диспозицією статті 172-11 КУпАП, може виражатися у самовільному залишенні військової частини або місця служби, нез'явлення без поважних причин на службу у разі звільнення 3 частини, відрядження, відпустки або лікувального закладу, призначення або переведення до іншого місця служби тощо.

Для правильної кваліфікації за ст. 172 13 КУПАП необхідно розуміти обсяг службових повноважень військової службової особи та об'єктивну сторону вчинюваних нею дій, що можуть бути пов'язані із перевищеннями влади чи службових повноважень.

Слід уважно підходити і до розмежування кваліфікацій адміністративних правопорушень, передбачених ст. ст. 172-13 та 1841 КУпАП. Основним критерієм тут буде визначення статусу майна. Якщо військовою службовою особою використовується майно, яке немає статусу військового, то відповідальність повинна бути за ст. 184-1 КУПАП.

Заволодіння шляхом зловживання військовою службовою особою своїм службовим становищем військовим майном може кваліфікуватися за ч. 2 ст. 410 КК України, а заволодіння нею шляхом зловживання своїм службовим становищем іншим майном - за ст. 191 КК України [4].

Для притягнення до адміністративної відповідальності військової службової особи необхідно встановити всі фактичні обставини правопорушення (складові об'єктивної сторони), у тому числі їі службовий стан, мотив, мету і характер вчинених дій, їх зв'язок із службовим становищем.

Зокрема, з об'єктивної сторони правопорушення, передбачене статтею 172-10 КУПАП вчиняється шляхом відмови від ви- конання наказу або інших законних вимог командира (начальника).

При цьому обов'язковою умовою притягнення військовослужбовця до адміністративної відповідальності $є$ відмова від виконання законного наказу або інших законних вимог командира (начальника). Адже відповідно до ст. 60 Конституції України ніхто не зобов'язаний виконувати явно злочинні розпорядження чи накази, а за віддання і виконання явно злочинного наказу настає юридична відповідальність [1, ст. 60]. Під законністю наказу або інших вимог командира, як зазначають науковці, слід розуміти наступну сукупність обставин: наявність у військової службової особи статусу командира та відповідних повноважень; формулювання обов'язкової для виконання підлеглими вимоги про вчинення певних дій по службі, їх відповідність законодавству, конкретність, реальність та змістовна належність до обсягу службових обов'язків підлеглих (за часом, місцем, змістом і характером вчинюваних дій), дотримання встановленого порядку доведення наказу або інших вимог до підлеглих. У зв'язку з цим адміністративна відповідальність відсутня, якщо відмова підлеглого стосується незаконного наказу командира .

Частина перша статті 402 КК України («Непокора») передбачає покарання за зовні тотожні правопорушення. Водночас різниця полягає у тому, що кримінальна відповідальність за непокору настає з урахуванням обставин вчинюваних правопорушником дій та їх суспільної небезпеки, зокрема за наявності:

- відкритої відмови виконати наказ начальника як більш зухвалої форми непокори (підлеглий у категоричній формі усно або письмово повідомляє, що він наказ виконувати не буде);

- негативних наслідків непокори або заподіяння істотної шкоди як матеріального, так і нематеріального характеру (непокора, висловлена у строю військовослужбовців або за їх присутності, що підриває авторитет командира; зрив виконання поставлених перед підрозділом завдань, порушення особистих чи майнових прав інших громадян тощо). 


\section{Адміністративне право}

Суб'єктивна сторона військових адміністративних правопорушень може мати будь-яку форму. Зокрема, необережну форму вини: особа передбачає, що через вчинювані нею дії можуть виникнути такі наслідки, як знищення (пошкодження) військового майна та пов'язані $з$ ними наслідки у вигляді заподіяння шкоди, але легковажно розраховує на відвернення вказаних наслідків або не передбачає можливості настання вказаних наслідків, хоч повинна була і могла їх передбачати (ст. ст. 172-12,172-15,172-19). Вина при скоєнні інших військових адміністративних правопорушень може бути умисною (ст. ст. 17214,172-16) або мати змішану форму (ст. ст. 172-13, 172-17, 172-18). Основним же критерієм відмежування проступків від кримінальних правопорушень, беззаперечно, залишається рівень суспільної небезпеки, хоча існують й інші критерії.

Так при розмежуванні кваліфікацій необережного знищення або пошкодження військового майна за ст. 172-12 КУпАП від ст. 412 КК України необхідно враховувати суспільно небезпечний характер завданих наслідків, а саме: заподіяння шкоди у великому розмірі або тяжких наслідків (смерть чи тілесні ушкодження одній або декільком особам).

Також і у випадку розмежування адміністративного і кримінально караного порушення правил поводження зі зброєю, iз речовинами і предметами, що становлять підвищену небезпеку для оточення (ст. 172-19 КУпАП і ст. 414 КК України), слід враховувати наслідки, які наступають після відповідних дій - ступінь тілесних ушкоджень заподіяних потерпілому або небезпечні наслідки для довкілля.

Слiд також враховувати, що при певних обставинах порушення правил несення прикордонної служби, які спричинили тяжкі наслідки, може також наступати кримінальна відповідальність за злочин, передбачений ст. 419 КК України [4].

До тяжких наслідків можна віднести вторгнення на територію України озброєних формувань, вчинення ворожих дій іноземними суднами щодо українського узбережжя, українських підводних та над- водних об'єктів, напад на прикордонну заставу, на дипломатичне представництво України чи консульську установу України в іноземній державі, провезення значної партії зброї чи інших предметів контрабанди поза пунктами прикордонного контролю, загибель людей, заподіяння їм тяжких тілесних ушкоджень, якщо це не викликалось умовами необхідної оборони, затримання злочинця або крайньої необхідності, знищення чи пошкодження інженерних споруд, інших важливих об'єктів державної власності тощо.

\section{Висновки та перспективи подальших досліджень}

Проблематика розмежування адміністративного i кримінальних правопорушень у військовій сфері раптово загострилася останніми роками, з огляду на ведення гібридної війни проти нашої держави та відвертої неготовності вітчизняної системи правосуддя до породженої цими подіями кількості правопорушень.

Тривалий час на сторожі законності у військовій сфері діяли військові прокуратури, ліквідація яких суттєво знизила готовність до подій, що сталися у 2013-2014 роках. Відновлення роботи військових прокуратур у серпні 2014 року дозволило не лише підвищити рівень правопорядку у військовій сфері, але й оптимізувати розмежування адміністративних і кримінальних правопорушень.

Окремо необхідно зазначити, що хоча рішення про наявність чи відсутність у діях військовослужбовця складу кримінального правопорушення прокурор приймає 3 урахуванням усіх зібраних матеріалів щодо фактичних обставин вчинених діянь (дій або бездіяльності), їх суспільної небезпечності та заподіяних наслідків матеріального i нематеріального характеру тощо, суттєвою лишається суб'єктивна складова такого рішення, що несе в собі потенційні корупційні ризики. Отже, попередження корупційних правопорушень з боку прокурорів є доволі актуальною сферою для подальших досліджень. Не менш актуальними об'єктами для майбутніх досліджень за розглянутою нами тематикою виступають i 


\section{АНОТАЦІЯ}

Авторами статті здійснено спробу надати родову характеристику війсъковим адміністративним правопорушенням, запропонувати умовні критерії, які можна використовувати для відокремлення правових інститутів адміністративноӥ та кримінальної відповідальності за правопорушення у війсъковій сфері.

Особливої гостроти проблематищі розмежування адміністративних та кримінальних правопорушень додає ведення проти України гібридної війни, що призводить до можливості використання окремих правопорушень, вчинених війсъковослужбовиями, як інформаиійних підстав для пропаганди та контрпропаганди.

Окреслено коло об'єктів правопорушень у війсъковій сфері. У найбільш узагальненому значенні, родовим об'єктом війсъкових адміністративних правопорушень є установлений порядок проходження війсъкової служби, зберігання та використання війсъкового майна, здійснення війсъковими службовими особами своїх функціональних обов'язків. При иьому безпосереднім об'єктом правопорушення, зокрема, може бути внутрішній порядок у війсъковій частині.

З’ясовано, що при квалібікащї дій правопорушників важливим є врахування відмінностей, які існують у різних родах війсък, їх дислокачї, підпорядкування, призначення або мети їх створення, спеціального статусу таких підрозділів тощо. При иъому, визначальним бактором розмежування квалібікації правопорушень може виступати суспільно небезпечний характер завданих наслідків.

Автори констатують важливість ролі військової прокуратури в розмежуванні адміністративних та кримінальних правопорушень у військовій сбері. Наголошується на своєчасності відновлення роботи війсъкової прокуратури та необхідності подальших досліджень особливостей ї діяльності в умовах ведення бойових дій.

Ключові слова: правосуддя, прокуратура, війсъкові прокурори, війсъкові адміністративні правопорушення, військові кримінальні правопорушення. такі проблеми, як: роль та місце військової прокуратури в системі правоохоронних органів в умовах іiі реформування (і особливо - в умовах військового конфлікту); особливості визначення рівня суспільної небезпеки дій та бездіяльності військовослужбовців тощо.

\section{Література}

1. Конституція України: прийнята на 5-й сесії Верховної Ради України 28 червня 1996 року// Відомості Верховної Ради України. - 1996.- № 30. - Ст.141.

2.Про прокуратуру// Закон України від 14.10.2014 року №1697-VII, Відомості Верховної Ради України (ВВР). 2015, № 2-3,CT. 12 .

3. Кодекс України про адміністративні правопорушення // Закон УРСР від 7.12.1984 р. № 8073-Х. Відомості Верховної Ради Української РСР (ВВР) 1984, додаток до № 51, ст.1122.

4. Кримінальний кодекс України // Закон України від 5.04.2001p. № 2341-III. Відомості Верховної Ради України (ВВРУ) 2001.№ 25, ст. 131.

5. Військові адміністративні правопорушення: Науково-практичний коментар глави 13-Б КУпАП / М.С.Туркот, А.В.Столітній, О.В.Міхед та ін., за ред. М.С.Туркота, 2020, 136с.

6. Про Державний бюджет України на 2021 рік // Закон України від 15.12.2020№ 1082 - IX. Голос України від 15.12.2020 р.

7. Статуту внутрішньої служби Збройних Сил України // Закон України від 24.03.1999 № 548-XIV. Відомості Верховної Ради України (ВВРУ) 1999.№ 22-23, ст. 194.

8.Кримінальний процесуальний кодекс України // Закон України від 13.04.2012p. № 4651-VI. Відомості Верховної Ради України (ВВРУ) 2013.№ 9-10, № 11-12, № 13,Ст. 88 .

\section{REGARDING THE DIFFERENTIA- TION OF MILITARY ADMINISTRATIVE OFFENSES FROM CRIMINAL OFFENSES}

The authors of the article made an attempt to provide a generic description of a military administrative offense, to propose conditional criteria that 


\section{Адміністративне право}

can be used to separate the legal institutions of administrative and criminal responsibility for offenses in the military sphere.

A particular acuteness of the problem of differentiating administrative and criminal offenses is added by the conduct of a hybrid war against Ukraine, which leads to the possibility of using certain offenses committed by military personnel as information reasons for propaganda and counterpropaganda.

The circle of objects of offenses in the military sphere is outlined. In the most generalized sense, the generic object of military administrative offenses is the established procedure for the passage of military service, the storage and use of military property, and the exercise by military officials of their functional duties. In this case, the direct object of the offense, in particular, may be the internal order in a military unit.
It was found that when qualifying the actions of offenders, it is important to take into account the differences that exist in different types of troops, their deployment, subordination, purpose or purpose of their creation, the special status of such units, and the like. At the same time, the determining factor in differentiating the qualifications of offenses may be the socially dangerous nature of the consequences caused.

The authors state the importance of the role of the military prosecutor's office in distinguishing between administrative and criminal offenses in the military sphere. The timeliness of the restoration of the work of the military prosecutor's office and the need for further research into the features of its activities in the context of the conduct of hostilities are noted.

Key words: justice, prosecutor's office, military prosecutors, military administrative offenses, military criminal offenses. 